\title{
Năng lực nội tại nền KHXH\&NV Việt Nam 2008-2019: Thấy gì từ những công bố khoa học của nước nhà?
}

\author{
Vũ Thị Hạnh \\ Trường Đại học Ngoại thương \\ Kinh tế và Dự báo (EFR) \\ Ngày 16 tháng 6 năm 2020
}

EFR (Hà Nội, 16-6-2020; http://kinhtevadubao.vn/chi-tiet/2-16723-nang-luc-noi-tai-nen-khxhnvviet-nam-2008-2019--thay-gi-tu-nhung-cong-bo-khoa-hoc-cua-nuoc-nha.html) - Năm 2019, tỷ lệ các công bố được thực hiện bởi các tác giả Việt Nam tăng mạnh và vượt mức các công bố có sự hợp tác giữa các tác giả Việt Nam và nước ngoài là 55,83\%.

Xuyên qua ngày tháng giãn cách xã hội do COVID-19 và cả chuỗi ngày hè nóng bức tháng 6/2020, công bố mới với những đánh giá ban đầu về năng lực nội tại của nghiên cứu khoa học và xã hội nhân văn Việt Nam đã xuất bản trên tạp chí Publications (tạp chí ISI/Scopus) [1].

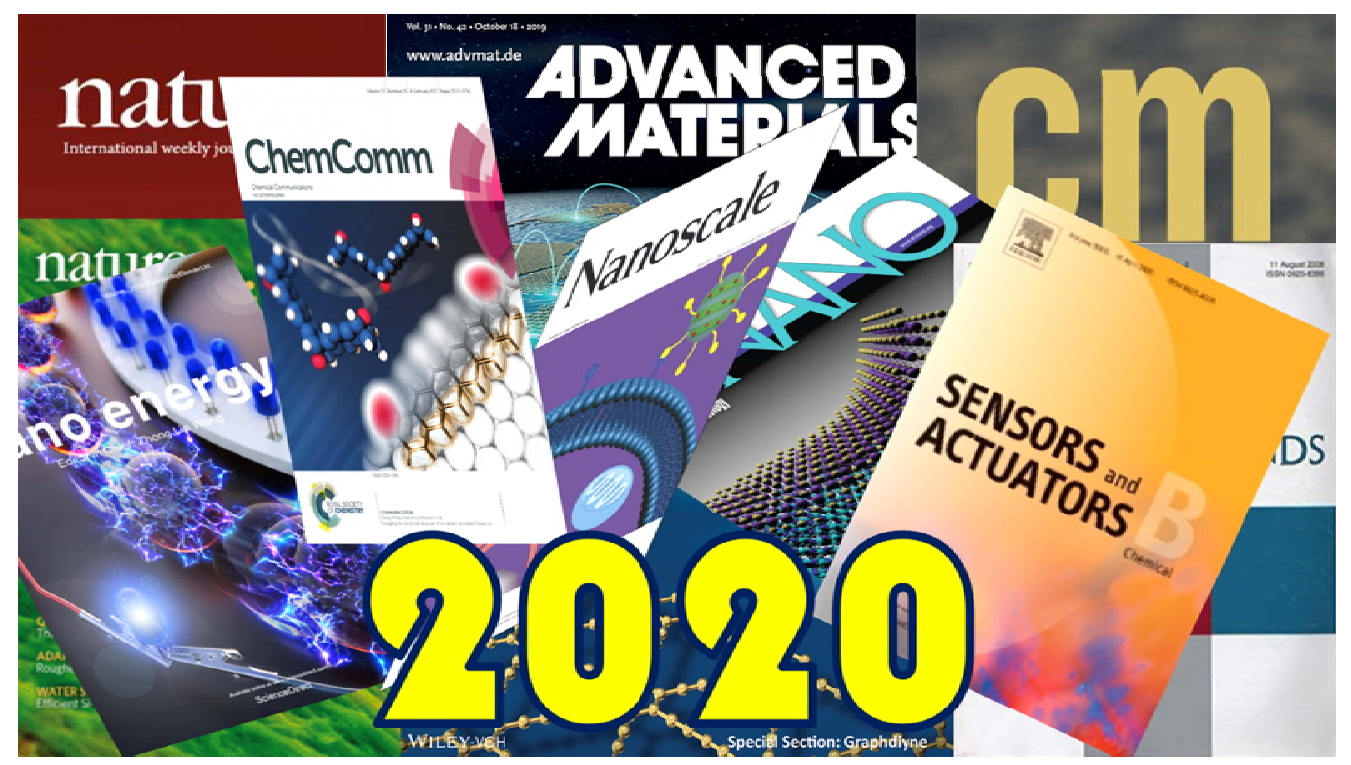

Năm 2019, tỷ lệ các công bố được thực hiện bởi các tác giả Việt Nam tăng mạnh

Sử dụng cơ sở dữ liệu gồm 2.040 tác giả Việt Nam hợp tác với 1981 tác giả nước ngoài và 3.160 bài báo được công bố trong giai đoạn 2008-2019, nhóm tác giả đã chỉ ra những đóng góp quan trọng của các nhà nghiên cứu trong nước đối với khoa học và xã hội nhân văn việt Nam với tỷ lệ tăng trưởng bình quân hàng năm đạt 22,33\% đặc biệt có $77,26 \%$ các công bố do các tác giả Việt Nam dẫn dắt. 
Ngạc nhiên hơn là trong năm 2019, tỷ lệ các công bố được thực hiện bởi các tác giả Việt Nam tăng mạnh và vượt mức các công bố có sự hợp tác giữa các tác giả Việt Nam và nước ngoài là 55,83\%. Bên cạnh đó, việc hợp tác nghiên cứu giữa các tác giả trong nước cũng cho thấy tín hiệu tiến triển tích cực. Tuy nhiên, mức độ tham gia của các tác giả nữ còn khá khiêm tốn chỉ chiếm 37,30\% cho thấy sự bất bình đẳng giới trong nghiên cứu khoa học và công bố quốc tế ở Việt Nam còn khá phổ biến.

Trong giai đoạn nghiên cứu, các tác giả Việt Nam đã hợp tác nghiên cứu với nhiều tác giả quốc tế, đến từ nền khoa học tiên tiến, như: Úc, Hoa Kỳ, Singapore, Anh, Pháp, Nhật Bản, Đức và Bỉ... Số tác giả công bố một mình (solo author) đối với các công bố trong lĩnh vực khoa học và xã hội nhân văn có xu hướng tăng còn phản ánh năng lực nghiên cứu độc lập của các tác giả Việt Nam.

Để có được những trái ngọt giai đoạn 2008-2019, chính phủ Việt Nam đã có những hỗ trợ hiệu quả cho giới khoa học và xã hội nhân văn, ví dụ thông qua Quỹ Phát triển khoa học và công nghệ Quốc gia (NAFOSTED) tài trợ cho các dự án nghiên cứu của các tác giả Việt Nam hướng tới việc đạt chuẩn công bố quốc tế. Cụ thể, tính đến năm 2019, NAFOSTED đã tài trợ cho hơn 10 ngàn nhà khoa học, 2400 bác sĩ được đào tạo nâng cao tay nghề và hơn 4 ngàn công bố (chỉ mục trong ISI Web of Science) thuộc 2800 dự án nghiên cứu được thực hiện bởi các nhà khoa học Việt Nam.

Đáng chú ý nhất chính là sự tham gia nghiên cứu, viết bài và đứng vai trò đồng tác giả của các bạn sinh viên đến từ trường Đại học Ngoại thương. Với sức trẻ của mình, các bạn sinh viên đã tham gia đóng góp, khai thác cơ sở dữ liệu và phát triển các sản phẩm nghiên cứu khoa học đạt chuẩn mực quốc tế. Mặc dù con đường nghiên cứu khoa học của các bạn trẻ còn nhiều thử thách phía trước, nhưng với nỗ lực tự thân và say mê tìm tòi, có thể tin tưởng tuổi trẻ sẽ tự mình điền thêm thêm những "con số" về đóng góp của chính mình vào cơ sở dữ liệu công bố quốc tế khoa học và xã hội nhân văn Việt Nam trong tương lai [2].

\section{Tham khảo}

[1] Ho MT, Vuong TT, Pham TH, Luong AP, Nguyen TN, Vuong QH. (2020). The internal capability of Vietnam social sciences and humanities: A perspective from the 2008-2019 dataset. Publications, 8(2): 32. https://doi.org/10.3390/publications8020032

[2] Vuong QH. (2019). Breaking barriers in publishing demands a proactive attitude. Nature Human Behaviour, 3(10): 1034. https://www.nature.com/articles/s41562-019-0667-6 